\title{
Industrial transformations and regional inequalities in Europe
}

\author{
Roberta Capello ${ }^{1} \cdot$ Silvia Cerisola ${ }^{1}$ id
}

Received: 31 August 2020 / Accepted: 7 December 2021 / Published online: 23 January 2022

(c) The Author(s), under exclusive licence to Springer-Verlag GmbH Germany, part of Springer Nature 2021

\begin{abstract}
An important channel through which less developed European countries have grown over the past twenty years is through the industrial transformation of their economies from low to higher value-added activities. The aim of the paper is to address the role of industrial transformation on regional imbalances, by analysing the different components of industrial productivity dynamics, namely the industrial composition, competition and reallocation effects. Based on both a shift-share analysis and a simulation analysis, the paper shows that the reallocation towards higher valueadded sectors in Central and Eastern European (CEE) countries could in fact lead to higher regional inequalities. Our empirical results lead us to claim that short-term normative interventions should go in the direction of supporting "modern and technologically advanced traditional sectors" rather than necessarily pushing CEE countries towards a high value-added industry specialization.
\end{abstract}

JEL Classification O4 $\cdot$ R1

\section{Introduction}

Regional inequality is back on the scene with great emphasis. As a matter of fact, after a long period of convergence, in 2008 inter-regional disparities started to increase, giving rise to a period of "reverse convergence" as has been labelled by DGRegio, the EU Directorate in charge of European Regional Policies. The increase of economic disparities reinforced social inequality, sense of frustration towards the EU as an institution, and the rise of populistic and nationalistic parties (Farole et al. 2018; OECD 2018; Dijkstra et al. 2020). The geography of social discontent (Rodríguez-Pose 2018) reflects rich and advanced areas in favour of socio-economic

Silvia Cerisola

silvia.cerisola@polimi.it

Roberta Capello

roberta.capello@polimi.it

1 ABC Department, Politecnico Di Milano, Milan, Italy 
integration and openness as opposed to poor, agricultural and less developed areas supporting a nationalistic view. Brexit is the most evident case of nationalism and of European dis-satisfaction, where the "leave" vote in the Referendum of 26th June 2016 was more pronounced in less prosperous regions than in more prosperous ones, and by people who sensed that they had suffered under modern globalization (McCann 2018). The situation will probably appear even more dramatic when the negative effects of the coronavirus crisis, especially on more fragile economies, will be clearer in the European economic trend. Such crisis, in fact, can easily push towards an even more uneven development.

Regional inequality is therefore a source of social dis-satisfaction and calls for the identification of adequate normative interventions. As a matter of fact, research on regional disparities has always been wide and articulated, both in terms of empirical analyses and of methods applied for measurement (for a review, see Ezcurra and Rodriguez-Pose 2019), most of them describing and interpreting the convergence or divergence of regional per capita GDP, following the initial contributions provided by Barro and Sala-i-Martin (1991 and 1992). ${ }^{1}$

Moreover, a strand of literature exists on the sources of regional disparities. These are in general attributed especially to institutional changes, namely the widening and deepening of the European Union, and particularly in the case of the large Central and Eastern European Countries (CEECs) enlargement in 2004 (Camagni et al. 2020; Casi and Resmini 2014, 2017; Popovici and Calin 2015; Iammarino and McCann 2013; Petrakos 2001; Pusterla and Resmini 2007; Resmini 2007).

One of the most quoted explanations for the existence of spatial disparities is the industrial structure of Central and Eastern European (CEE) countries, with respect to the Western, more modern, economies. The 7th Cohesion Report, the most important official document of DGRegio reporting on the socio-economic conditions of European regions and on their evolution, largely quotes the significant specialization in low value-added sectors, usually identified as traditional sectors, of CEE countries as a source of regional inequality (European Commission 2017). Such specialization explains the lagging behind of such countries and puts forward the question whether policies to support industrial transformation towards more advanced sectors should be developed. Rural regions specialized in a traditional sector like agriculture are the poorest areas; the support by EU policies to transform their economies towards industrial activities is something strongly debated. However, the same 7th Cohesion Report rightly underlines that the catching-up in productivity of CEE countries is especially registered in low value-added sectors-agriculture and industry. This is true especially before the 2008 economic crisis, but also in the years of crisis, even if at less pronounced rates.

Industrial transformation is broadly defined as changes in the productive structure, i.e. in the mix of sectors present in a country or region. In the debate on CEE

\footnotetext{
1 For analyses on convergence and divergence trends, see, for example, Abreu and de Groot (2005), Dall'Erba and Le Gallo (2008), Artelaris et al. (2010), Petrakos et al. (2011), Smetkowski and Wójcik (2012), Ezcurra and Rodriguez-Pose (2013), Crespo-Cuaresma et al. (2014), Piribauer (2016), Ramajo and Hewings (2018).
} 
countries, industrial transformation is expected to change the composition of sectors towards higher value-added ones, with a positive effect on productivity growth through: i) a mix of local sectors in the region that increase their productivity more than the European average. This is potentially possible through a process of technological progress at the sectoral level (modernization effect); ii) the presence of local sectors that are more competitive than the same sectors somewhere else (efficiency effect); iii) a reallocation of the labour force from low to high value-added sectors (reallocation effect).

A legitimate question then is whether the industrial transformation processes lead to decreasing inequalities in the EU, through an increase in productivity in less developed countries. Normative interventions, in fact, must be adjusted to the process that prevails and that drives productivity dynamics. This question is particularly relevant in Europe, characterized by two blocks of countries (Western and Eastern ones) that, for historical reasons, register a different industrial structure, a different industrial transformation and different productivity growth and levels.

The paper has the aim to reply to such a question and to identify whether the effect of productivity growth on inequalities in Europe is the result of a modernization, an efficiency or a reallocation effect, understanding the weight of each effect on regional inequality to guide policy actions.

The paper starts by describing the relatively scant existing literature on this specific topic (Sect. 2), preparing the ground to the analysis of how structural changes in the industrial structure influence regional imbalances, disentangling productivity growth in its three components (Sect. 3), and simulating their specific individual role on regional disparities (Sect. 4). The final goal is to guide policy interventions in favour of an industrial transformation supporting the reduction of regional imbalances (Sect. 5).

\section{Sectoral perspectives on the role of productivity in regional inequality}

A special attention to the dynamic role of the transformation of the production structure on spatial disparities is largely present in official documents of institutions (like the European Union). However, relatively limited academic research is produced on such last issue, especially at the sub-national level.

Within the existing literature on inter-regional convergence processes, rather few pioneering and interesting works have looked in depth at the relationship between productivity growth and industrial specialization. The sectoral perspective has been recognized as deserving particular attention since regional industrial specialization highly affects the aggregate growth patterns of the economy and its changes. In fact, "sectoral analysis is very important because it highlights crucial elements, like structural changes and differences in sectoral productivity, that remain unseen in the aggregate approach" (Paci 1997, p. 611). From the empirical results, spatial inequality implications are discussed.

According to these observations, the sectoral structure has attracted the interest as a source of regional convergence in labour productivity. In particular, the trends 
in sectoral dualism (agriculture vs non-agriculture) (Paci and Pigliaru 1999) and the progressive homogenization of the regional productive structure (industrial composition) through cross-sectoral labour reallocations (industrial transformations) turn out in the literature to be the sources of regional convergence in labour productivity according to a gradual process leading to subsequent stages of development (Paci and Pigliaru 1997; Cuadrado et al. 1999; Cuadrado et al. 2000; Carluer and Gaulier 2005).

In an effort to separate out the different components of productivity, mainly through different and expanded versions of the traditional shift-share analysis initially introduced by Perloff et al. (1960), interesting works emerged that try to single out the role of industrial composition and competition in regional convergence, especially in terms of productivity levels (Esteban 2000; Ezcurra et al. 2005; Ezcurra and Pascual 2007). In this perspective, through a simulation analysis, differences in regional productivity levels are decomposed in three parts, the mix of sectors in the region, the efficiency of particular sectors in specific regions, and their covariance, i.e. the composition of particularly dynamic sectors in the region, so to calculate the weight of each component.

In a dynamic perspective, a decomposition approach was applied to aggregate productivity growth with the aim to separate out the growth of productivity in individual sectors from the shifting in the sectoral distribution (Villaverde and Maza 2008). Through a beta convergence econometric approach, the accounting decomposition of the aggregate productivity convergence process reveals the sectoral productivity growth effect to be the only responsible for regional productivity catching up.

This relatively scant existing literature on the linkage between an industrial approach to productivity growth and spatial inequalities would benefit from a study that can clearly compute the weight of each single component of productivity growth on regional disparities, since it would produce a result of great relevance for policy makers, especially when spatial disparities are disentangled into their international and intranational components.

This paper presents a simulation exercise directly applied to an indicator of regional wealth disparities, making use of per capita GDP instead of labour productivity. Although this last measure has been proved to be essential in explaining differences in per capita income, it overlooks differences in employment rates. The study is applied to regions belonging to all EU countries plus UK, providing a larger geographical scope with respect to previous analyses. This geographical coverage allows to particularly compare the industrial transformation processes currently taking place in CEE countries w.r.t. Western countries and to assess the way in which such processes affect the overall level of spatial disparities.

\section{Regional productivity dynamics and its components}

\subsection{The methodology and the data}

As it is well known, productivity dynamics are much in favour of CEE countries. CEE countries largely outperform Western member states in all sectors, showing 
annual average productivity growth rates definitely higher than those of the other European countries (see Table A1 in Annex). Evidence is scarce on whether productivity growth is the result mainly of a modernization of existing sectors, of an increase in productivity of local sectors, or a shift of labour force towards more productive sectors.

In this section, we apply the shift-share analysis to decompose the aggregate productivity growth into its three main components following Camagni (1980): (i) the presence in the region of a specific combination of industries with different productivity growth (MIX or composition effect) capturing a sectoral modernization effect, (ii) a different productivity growth in an industry in a specific region with respect to the same industry located somewhere else (DIFF or competition effect), measuring an efficiency effect, (iii) the reallocation of employment over time towards sectors with different productivity levels, representing the sectoral reallocation effect.

The following formula is applied:

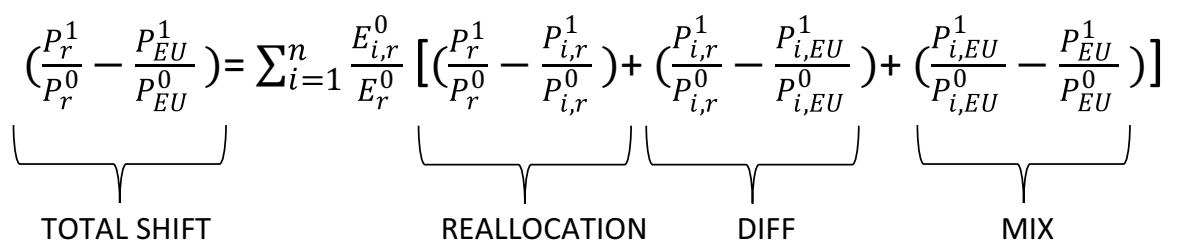

where $P$ stands for productivity (measured as GDP PPS per worker), $E$ represents employment, $r$ is the NUTS2 region, $E U$ is Europe (reference area), $i$ is the sector, $n$ is the total number of sectors, and there are two time periods ( 0 and 1 , where 0 is prior to 1$)$.

Since the final aim of the present work is to assess the impact of different components of productivity growth on regional disparities, traditionally measured in PPS even by the EU when designing the cohesion policy, data chosen were GDP in PPS. ${ }^{2}$

Regional (NUTS2) aggregate data on GDP PPS are made available by Eurostat and distributed among the different sectors based on the GVA by sector provided by Cambridge Econometrics. The sectoral disaggregation is at the level of six macro-sectors, namely agriculture, industry, construction, wholesale and retail trade, financial and business services, non-market services. ${ }^{3}$ The sectoral disaggregation strongly influences the results since the shift-share analysis is sensitive to it. A low disaggregation of sectors leads to a decomposition where the DIFF component is overestimated with respect to the MIX, which may in fact hide rather different industrial sectors, which partially influences the DIFF effect. However, we believe this does not limit, or interfere with, the interest in the general results.

The shift-share analysis is performed on the European (EU+UK) NUTS2 regions and on the six sectors listed before and applied to two separate periods of

\footnotetext{
2 As Table A1 in Appendix shows, the ranking of sectors in terms of productivity growth calculated with GDP in PPS or at constant prices does not change.

${ }^{3}$ Unfortunately, sectoral disaggregation by manufacturing sectors at NUTS2 level is not available for all the European countries.
} 
(a) Relative regional productivity growth

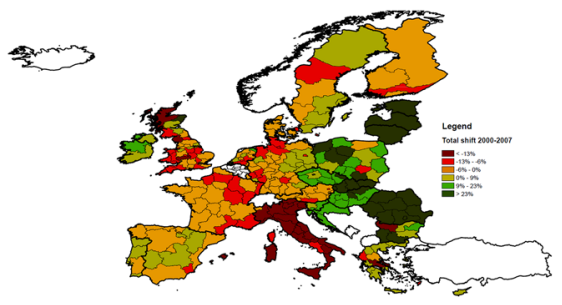

(c) Regional efficiency effect (DIFF)

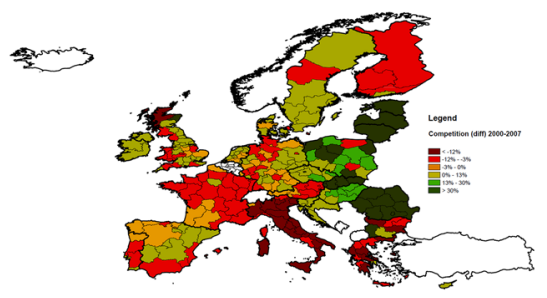

(b) Modernisation effect (MIX)

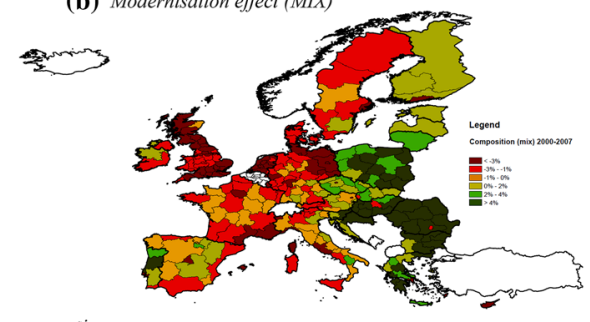

(d) Reallocation effect

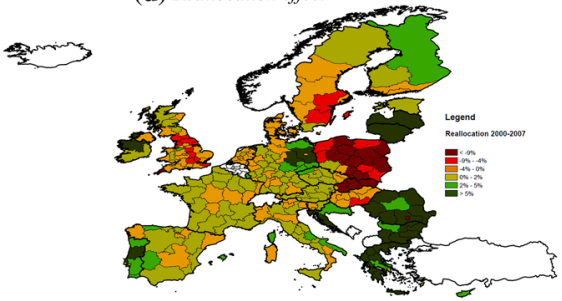

Regional GDP data for Belgium are available only since 2003. Therefore, Belgium is not included in the analysis for the 2000-2007 period.

Fig. 1 Shift-share analysis: total shift and its components 2000-2007

time, 2000-2007 and 2008-2015. The choice of these two periods is due to the fact that they capture an expansionary and a decline period, respectively. In this way, we make sure that our results do not mix up two extremely different economic trends, which would risk interfering with the interpretation of the outcome.

\subsection{The results}

The results are here displayed for the period 2000-2007 (Fig. 1). As a robustness check, the analysis is carried out also for the subsequent period (2007-2015), during which regional inequality increased, and results do not change drastically, highlighting their structural nature (Figs. A1 and A2 in Annex).

In particular, Fig. 1a represents the regional productivity growth. Results confirm at regional level what is known at the aggregate level: CEE countries experience a higher-than-average productivity growth. Figure $1 \mathrm{~b}-\mathrm{d}$ presents, respectively, the modernization (MIX), the reallocation and the aggregate efficiency effects (DIFF).

The modernization (MIX) effect is strongly present in Eastern regions, with a few exceptions in the Western part of Europe (Fig. 1b). This result can easily be interpreted by the relevance of the agricultural and industrial sectors in these regions. These sectors are indeed those registering the highest productivity growth, both in terms of PPS and in terms of real GDP values (Table A1 in Appendix), for two different reasons: for agriculture, this is the result of the strong modernization process undergoing; for the manufacturing sector, this is probably the presence of foreign direct investments. 
However, as can be inferred by the scale of the legend in Fig. 1c, the most important source of aggregate productivity dynamics is the regional efficiency (DIFF) effect, even if this is partially due to the level of sectoral aggregation available. This is fully consistent with the findings of previous works (e.g. Esteban 2000; Ezcurra et al. 2005; Ezcurra and Pascual 2007). CEE countries benefit overall by a positive regional efficiency effect, which means that their sectors register a particular increase in productivity with respect to the same sectors in the rest of Europe. In the case of agriculture, the margins for productivity increases in CEE countries were particularly high with respect to agriculture in Western countries, through modernization processes. The very positive DIFF effect in CEE countries is also due to the industrial sector, while it demonstrates the fragility of some Southern countries' economies, especially Italy and Greece.

The situation appears patchier when looking at sectoral reallocation (Fig. 1d). In CEE countries, the contribution of the reallocation component is relevant. However, differences emerge among countries. On the one hand, reallocation to sectors characterized by a higher level of productivity takes place, especially in Bulgaria and Romania (last entrants), where the reallocation of employment from agriculture to industry and to services is large. On the other hand, reallocation to sectors with a lower level of productivity characterizes countries like Poland, Hungary or Slovakia. In these last cases, the employment is likely to have moved towards scarcely productive services (e.g. public and private services). This is consistent with the stages of development theory and reminds that, even within the CEE area, different countries are at a different stage of their development trajectory. Looking at the two periods, sectoral reallocation during the crisis seems to be overall less relevant and to show a generalized shift towards lower productivity sectors, with Germany and Poland being the main exceptions in this respect (Fig. Alin Appendix).

The dynamic of productivity described and analysed along the present section is evidently associated with (in)equality. However, the linkage is not immediate and calls for an additional empirical analysis. Based on an original simulation procedure presented in the next section, the analysis is able to measure the effects of productivity dynamics on regional imbalances.

\section{Regional productivity components and regional imbalances}

In order to compute the impact of each component of productivity growth on regional disparities, we perform a simulation exercise to highlight the different effects. The simulation works by assuming that, one at a time, each component has no effect, keeping the other components in place. The difference between the actual GDP and the simulated GDP obtained by assuming the inexistence of one component provides the weight of that individual component and, from there, its weight on the levels of regional disparities in terms of per capita GDP. As mentioned before, GDP per capita is here preferred with respect to GDP over employment (labour productivity), consistently with what is the traditional measurement of regional disparities considered by the European Commission itself in planning the cohesion policy. 


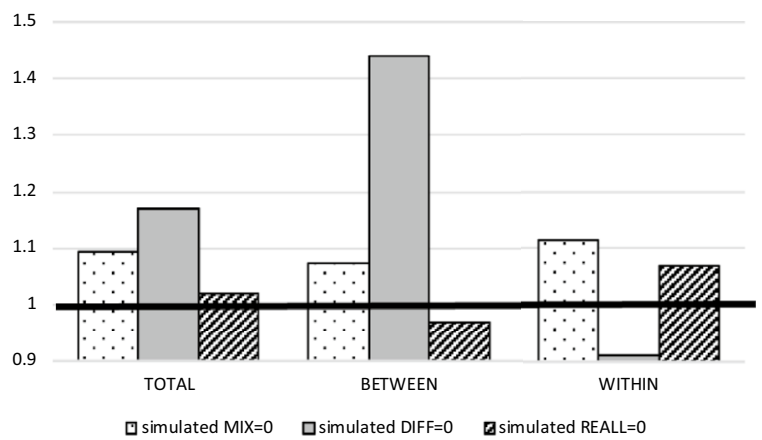

The values are standardized to 1 for each component separately. For this reason, the sum of the two components does not give the total

Fig. 2 Simulations on regional disparities: total Theil index and its between-country and within-country components (actual value $=1)-2007$

The simulated GDP PPS is applied to compute a Theil index of regional wealth disparities, through the following formula:

$$
T=\sum_{r} \frac{Y_{r}}{Y_{E U}} \ln \frac{Y_{r} / P_{r}}{Y_{E U} / P_{E U}}=\sum_{c} \frac{Y_{C}}{Y_{E U}} \ln \frac{Y_{C} / P_{C}}{Y_{E U} / P_{E U}}+\sum_{C} \frac{Y_{C}}{Y_{E U}} \sum_{r \subset} \frac{Y_{r}}{Y_{C}} \ln \frac{Y_{r} / P_{r}}{Y_{C} / P_{C}}
$$

where $Y$ stands for GDP PPS, $P$ for population and the indexes $E U, C$ and $r$ stand, respectively, for Europe, country and NUTS2 region. As can be clearly seen in Eq. 2, the total Theil index (the first element) can be decomposed into a "between-country" component and a "within-country" component (Akita 2003; Butkus et al. 2018), an important aspect since the two components have demonstrated to have completely different trends over time (see Camagni et al. 2020).

Three simulations are performed. In particular:

(1) In the first one, all European regions are assumed to have a composition of sectors with the same productivity growth. In this case, the sectoral composition is that of the European average (MIX $=0$ );

(2) In the second one, each sector is assumed to have the same productivity growth everywhere in Europe, i.e. that of the sectoral European average (DIFF $=0)$;

(3) In the third one, no employment shift among sectors is assumed anywhere $($ REALL $=0)$.

The results of the three simulations are displayed in Fig. 2, which reports the level of total Theil index - and its between and within components - in each of the simulations, compared to the actual total, between and within Theil level, expressed with a line at the level of 1 .

When we assume that all regions in Europe have a composition of sectors with the same productivity growth, the simulation leads to an overall increase in regional 
disparities (Fig. 2), which holds for both between- and within-country disparities. This result is explained by the fact that when the same modernization effect (MIX) is imposed to all the regions, CEE countries-already poorer than the rest of the EU-lose their comparative advantage linked to their specialization in agriculture and industry, two sectors characterized by significant productivity growth in CEE countries (Table A1 in Annex). This result also witnesses that regional efficiency, typically higher in CEE countries w.r.t. Western ones (Fig. 1c), is not sufficient to counterbalance the loss of a particularly favourable mix of dynamic sectors.

This mechanism explains well the growth of the between-country component of the Theil index in the simulation (Fig. 2). Interestingly, the modernization (MIX) effect plays an important role also in intranational disparities. Weaker areas, usually specialized in agriculture and industry, are in fact further penalized from assuming a similar composition across regions in Europe (Fig. 2).

The results of regional disparity levels obtained when we impose each sector to have a spatially homogenous productivity growth show the largest change in regional disparities, which overall worsen (Fig. 2). This outcome is explained by two concomitant effects: the loss of efficiency that CEE countries have in their agriculture and industry sectors, and the increase in efficiency that stronger countries-e.g. Italy and France-register. Consequently, the negative effect on regional disparities is particularly apparent for the between-country component (Fig. 2). Interestingly, the simulation generates a decrease in within-country disparities. This result comes from the fact that strong areas in each country are penalized by having the same sectoral productivity growth as the poorer ones (Fig. 2).

The outcome of a potentially inexistent reallocation effect is a slight rise in total regional disparities (Fig. 2), which is in fact the result of lower between-country disparities and higher within-country disparities (Fig. 2). This outcome is probably led by the shift of employment from higher value-added industrial activities to lower value-added traditional service activities (e.g. wholesale and retail trade), which has characterized CEE economies in their evolution to more advanced stages of development. The simulation in fact advantages some CEE countries, namely Poland, Slovakia and Hungary (Fig. 1d), and leads to an overall reduction of between-country disparities (Fig. 2). On the other hand, within-country disparities grow (Fig. 2) as an effect of the concentration of development in core regions (see, for instance, Gorzelak and Smętkowski 2010, Smętkowski 2013; Psycharis et al. 2019).

If the simulation is run on a different period (2007-2015), results remain valid, justifying once again the structural nature of the industrial transformation (see Fig. A2 in Annex).

\section{Conclusions}

The interpretation of the causes of regional disparities remains a crucial aspect in a period in which spatial disequilibria are not only sources of social inequality but also sources of political instability, reinforced by the rise of populist and nationalist parties. In this respect, one of the causes of spatial unbalances has been seen in the specialization of less advanced countries and regions in lower value-added sectors, 
which, however, have been showing the highest growth rates in productivity in the last twenty years.

The aim of the paper was to address this issue, by analysing the sources of structural changes in the regional industrial fabric contributing to productivity dynamics, an approach still missing in the literature. In particular, changes in productivity growth due to the composition of sectors present in the region (modernization effect), or to the competitiveness of the local sectors (regional efficiency effect), or to the reallocation of resources among sectors (reallocation effect), obtained through the decomposition of productivity growth trends, were investigated for the European regions.

The results obtained through the innovative simulation procedure proposed univocally suggest that, in the last ten to fifteen years, higher productivity growth in CEE countries, particularly in their specialization sectors-i.e. agriculture and industry-lowers between- and within-country regional disparities. In this sense, less advantaged countries seem to be already on a positive path as far as convergence through productivity growth is concerned.

In greater detail, the picture resulting from the analysis stresses the importance of some ongoing structural changes in the industrial fabric. The modernization of the agricultural sector in CEE countries, based on labour-saving technical progress, is particularly effective. This seems to be, indeed, a viable way to strengthen weaker regions in CEE countries and consequently to reduce overall spatial imbalances. In fact, although a physiological and positive transition process from less to more productive sectors is currently taking place in CEE countries and regions, changing their agricultural and industrial nature, trying to transform them in areas specialized in high value-added services, does not seem to be necessarily the best way to improve their productivity. Sectoral transition is, indeed, a difficult task, since it depends on the long-lasting sectoral composition of countries and regions and since job-specific skills are not easily transferable from one sector to another.

The overall results remind that regional development is a place-specific process, calling for the reinforcement of specific characteristics of individual regions, and not necessarily the result of a high value-added sector-driven approach (Capello 2014; Capello and Kroll 2016).

Favouring the restructuring of an efficient, modern and productive agricultural sector appears therefore more suitable for the development of less advantaged regions and more effective in the reduction of inter-regional disparities than it is expected. The "Dutch model" of efficient and modern agriculture (Blum 1991) could be an interesting best practice for CEE agricultural areas to follow. In this sense, cohesion policy could be used to accompany such a process and keep the convergence path.

\section{Appendix}

See Table A1. 
Table A1 Labour productivity growth by sectors, groups of countries and periods of time

Labour productivity by sector Compound annual growth rate $(\%)$

Time periods Sec-

200-2007-2015

tors and total

GDP PPS GDP const. prices GDP PPS GDP const. prices

\begin{tabular}{|c|c|c|c|c|c|}
\hline \multirow[t]{3}{*}{ Agriculture } & CEECs & $8.76 \%$ & $6.35 \%$ & $4.13 \%$ & $2.42 \%$ \\
\hline & Western countries & $3.69 \%$ & $1.92 \%$ & $2.52 \%$ & $1.34 \%$ \\
\hline & EUROPE & $6.27 \%$ & $4.21 \%$ & $3.28 \%$ & $2.00 \%$ \\
\hline \multirow[t]{3}{*}{ Industry } & CEECs & $8.68 \%$ & $6.41 \%$ & $5.40 \%$ & $3.62 \%$ \\
\hline & Western countries & $4.85 \%$ & $3.01 \%$ & $3.04 \%$ & $1.76 \%$ \\
\hline & EUROPE & $5.25 \%$ & $3.03 \%$ & $3.42 \%$ & $1.90 \%$ \\
\hline \multirow[t]{3}{*}{ Construction } & CEECs & $2.23 \%$ & $-0.24 \%$ & $2.97 \%$ & $1.47 \%$ \\
\hline & Western countries & $1.59 \%$ & $-0.90 \%$ & $0.63 \%$ & $-0.35 \%$ \\
\hline & EUROPE & $1.52 \%$ & $-0.42 \%$ & $0.94 \%$ & $-0.38 \%$ \\
\hline \multirow{3}{*}{$\begin{array}{l}\text { Wholesale and } \\
\text { retail trade }\end{array}$} & CEECs & $4.45 \%$ & $2.20 \%$ & $2.01 \%$ & $0.48 \%$ \\
\hline & Western countries & $2.35 \%$ & $0.51 \%$ & $1.08 \%$ & $-0.04 \%$ \\
\hline & EUROPE & $2.57 \%$ & $0.53 \%$ & $1.18 \%$ & $-0.06 \%$ \\
\hline \multirow{3}{*}{$\begin{array}{l}\text { Financial and busi- } \\
\text { ness services }\end{array}$} & CEECs & $3.53 \%$ & $1.25 \%$ & $1.33 \%$ & $-0.34 \%$ \\
\hline & Western countries & $2.30 \%$ & $0.73 \%$ & $0.64 \%$ & $-0.55 \%$ \\
\hline & EUROPE & $2.36 \%$ & $0.65 \%$ & $0.65 \%$ & $-0.65 \%$ \\
\hline \multirow{3}{*}{$\begin{array}{l}\text { Non-market ser- } \\
\text { vices }\end{array}$} & CEECs & $5.37 \%$ & $3.17 \%$ & $2.93 \%$ & $1.24 \%$ \\
\hline & Western countries & $2.66 \%$ & $1.13 \%$ & $0.94 \%$ & $-0.38 \%$ \\
\hline & EUROPE & $2.98 \%$ & $1.32 \%$ & $1.14 \%$ & $-0.27 \%$ \\
\hline \multirow[t]{3}{*}{ Total } & CEECs & $6.94 \%$ & $4.64 \%$ & $3.54 \%$ & $1.89 \%$ \\
\hline & Western countries & $2.95 \%$ & $1.25 \%$ & $1.35 \%$ & $0.14 \%$ \\
\hline & EUROPE & $3.50 \%$ & $1.59 \%$ & $1.64 \%$ & $0.28 \%$ \\
\hline
\end{tabular}

See Figs. A1 and A2. 
(a) Total shift

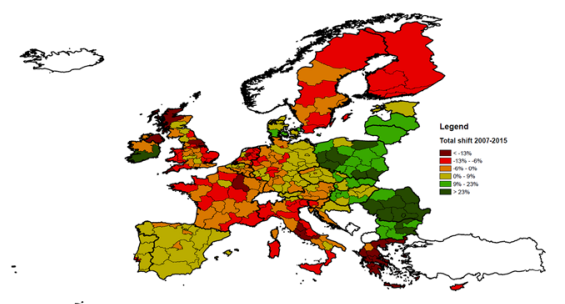

(c) Regional efficiency effect (DIFF)
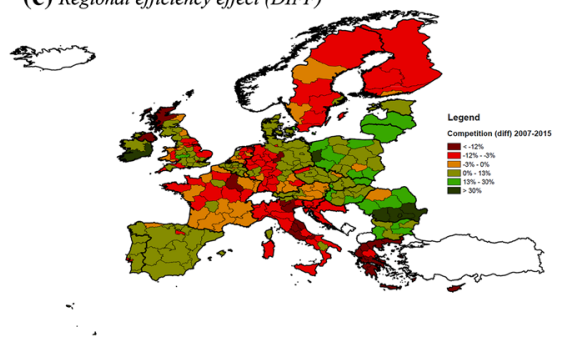

(b) Modernisation effect (MIX)

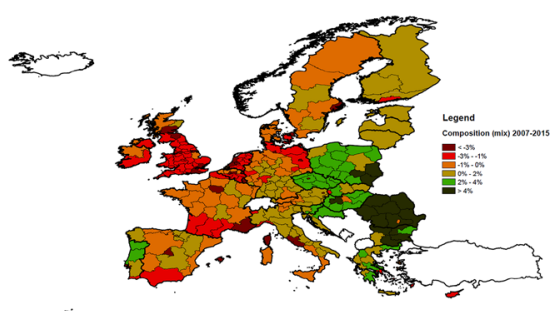

(d) Reallocation effect

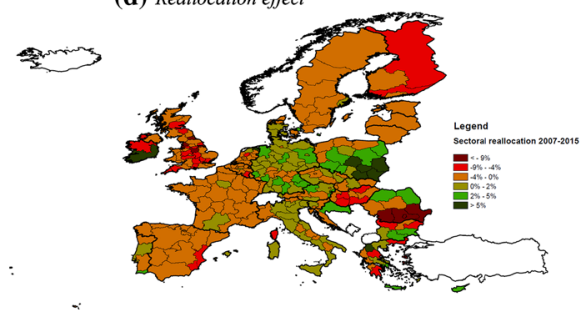

Fig. A1 Shift share analysis: total shift and its components 2007-2015

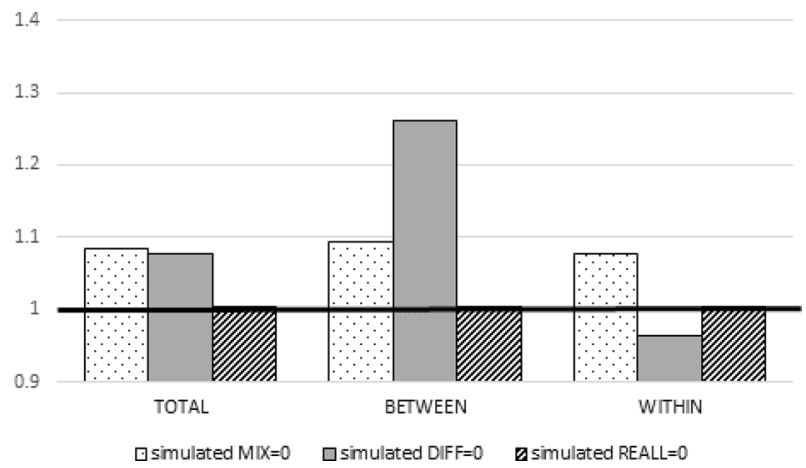

Fig. A2 Simulations on regional disparities: total Theil index and its between-country and within-country components (actual value $=1)-2015$

\section{References}

Abreu M, de Groot H (2005) A meta-analysis of $\beta$-convergence: the legendary 2\%. J Econom Surv 19(3):389-420

Aghion P, Caroli E, García-Penalosa C (1999) Inequality and economic growth: the perspective of the new growth theories. J Econom Literat 37:1615-1660

Akita T (2003) Decomposing regional income inequality in China and Indonesia using two-stage nested Theil decomposition method. Ann Reg Sci 37(1):55-77

Artelaris P, Kallioras D, Petrakos G (2010) Regional inequalities and convergence clubs in the European Union new member-states. Eastern J Eur Stud 1(1):113-133

Barro R, Sala-i-Martin X (1991) Convergence across states and regions. Brooking Papers on Econom Activity 1:107-182 
Barro R, Sala-i-Martin X (1992) Convergence. J Polit Econ 100:407-443

Blum A (1991) What can be learned from a comparison of two agricultural knowledge systems? The case of The Netherlands and Israel. Agr Ecosyst Environ 33(4):325-339

Butkus M, Cibulskiene D, Maciulyte-Sniukiene A, Matuzeviciute K (2018) What is the evolution of convergence in the EU? decomposing EU disparities up to NUTS3 Level. Sustainability 10:15-52

Camagni R, Capello R, Cerisola S, Fratesi U (2020) Fighting gravity: institutional changes and regional disparities in the EU. Econ Geogr. https://doi.org/10.1080/00130095.2020.1717943

Camagni R. (1980) Il mutamento strutturale nell'industria di una regione europea, Economia e Politica Industriale, n. 26

Capello R (2014) Smart specialization strategy and the EU policy reform: introductory remarks. Scienze Regionali Italian J Reg Sci 13(1):5-14

Capello R, Kroll H (2016) From theory to practice in smart specialization strategy: emerging limits and possible future trajectories. Eur Plan Stud 24(8):1393-1406

Capello R., M. Laffi, and C. Lenzi (2019) Spatial trends in 4.0 technologies across European regions: New Islands of Creative Innovation, paper presented at the 59th ERSA conference, in Lyon, 27-30 August

Carluer F, Gaulier G (2005) The impact of convergence in the industrial mix on regional comparative growth: Empirical evidence from the French case. Ann Reg Sci 39:85-105

Carree MA, Klomp L, Thurik AR (2000) Productivity convergence in OECD manufacturing industries. Econ Lett 66:337-345

Casi L, Resmini L (2014) Spatial complexity and interactions in the FDI attractiveness of regions. Pap Reg Sci 93(S1):51-78

Casi L, Resmini L (2017) Investimenti diretti esteri, identità regionali e crescita. Scienze Regionali, Italian J Reg Sci 16(2):171-200

European Commission (2017) My REGION, My Europe, Our Future, accessed 27 Jan 2020 at https://ec. europa.eu/regional_policy/sources/docoffic/official/reports/cohesion7/7cr.pdf.

Crespo-Cuaresma J, Doppelhofer G, Feldkircher M (2014) The determinants of economic growth in European regions. Reg Stud 48(1):44-67. https://doi.org/10.1080/00343404.2012.678824

Cuadrado-Roura JR, Garcia-Greciano B, Raymond JL (1999) Regional convergence in productivity and productive structure: the spanish case. Int Reg Sci Rev 22(1):35-53

Cuadrado-Roura JR, Garcia-Greciano B, Raymond JL (2000) Regional convergence in productivity and productive structure: the spanisg case. Int Reg Sci Rev 22(1):35-53

Dall'Erba S. and J. Le Gallo, (2008) Regional convergence and the impact of European structural funds over 1989-1999: a spatial econometric analysis. Pap Reg Sci 87(2):219-244

Dijkstra L, Poelman H, Rodríguez-Pose A (2020) The geography of EU discontent. Reg Stud 54(6):737753. https://doi.org/10.1080/00343404.2019.1654603

ESPON (2019) Territorial Trends in Technological Transformation, Project led by Politecnico di Milano, https://www.espon.eu/transregecon.

Esteban J (2000) Regional convergence in Europe and the industry mix: a shift-share analysis. Reg Sci Urban Econ 30:353-364

Ezcurra R, Pascual P (2007) Spatial disparities in productivity in Central and Eastern Europe. East Eur Econ 45(3):5-32

Ezcurra R, Rodriguez-Pose A (2013) Does economic globalization affect regional inequality? A CrossCountry Anal, World Develop 52:92-103

Ezcurra R, Rodriguez-Pose (2019) Measuring the regional divide. In: Capello R, Nijkamp P (eds) Handbook of Regional Growth and Development Theories - Revised and extended, 2nd edn. Edward Elgar, Cheltenham, pp 329-452

Ezcurra R, Gil C, Pascual P, Rapún M (2005) Regional inequality in the European Union: Does industry mix matter? Reg Stud 39(6):679-697

Farole T., S. Goga, and M. Ionescu-Heroiu (2018) Rethinking Lagging Regions - Using Cohesion Policy to deliver on the potential of Europe's regions, World Bank Report on the European Union, World Bank Group.

Fisher A (1933) Capital and the growth of knowledge. Econ J 43(171):379-389

Hoover EM (1948) The Location of Economic Activity. Mc-Graw-Hill, New York

Hoover E. M. and A. Fisher (1949) Research in regional economic growth, Problems in the Study of Economic Growth, NBER, New York.

Iammarino S, McCann Ph (2013) Multinationals and economic geography. Edward Elgar, Cheltenham 
Kitson M, Martin R, Tyler P (2004) Regional Competitiveness: an elusive yet key concept? Reg Stud 38(9):991-999

Mazzucato M, Cimoli M, Dosi G, Stiglitz JE, Landesmann MA, Pianta M et al (2015) Which industrial policy does Europe need? Intereconomics 50(3):120-155

McCann P (2018) The trade, geography and regional implications of Brexit. Pap Reg Sci 97(1):3-8

OECD (2018) Productivity and Jobs in a Globalised World - (How) Can All Regions Benefit?.

Paci R (1997) More similar and less equal: economic growth in the european regions. Weltwirtschaftliches Archiv 133(4):609-634

Paci R, Pigliaru F (1999) Is dualism still a source of convergence in Europe? Appl Econ 31:1423-1436

Perloff, H., Dunn, E., Lampard, E., Muth, R. (1960), Regions, resources, and economic growth, Johns Hopkins Press.

Petrakos G (2001) Patterns of regional inequality in transition economies. Eur Plan Stud 9(3):359-383

Petrakos G, Kallioras D, Anagnostou A (2011) Regional convergence and growth in Europe: understanding patterns and determinants. Eur Urban and Reg Stud 18(4):375-391

Pianta M (2014) An industrial policy for Europe. Seoul J Econom 27(3):277-305

Piribauer P (2016) Heterogeneity in spatial growth clusters. Empirical Econom 51(2):659-680. https:// doi.org/10.1007/s00181-015-1023-y

Popovici OC, Calin A (2015) The effects of enhancing competitiveness on FDI inflows in CEE Countries. Eur J Interdis Stud 7(1):55-65

Psycharis Y, Kallioras D, Pantazis P (2019) Regional inequalities in Central and Eastern European countries: the role of Capital regions and Metropolitan areas. In: Sliwinski A., Polychronidou P. and Karasavvoglou A. (eds), Development of the economy and finance of Southeastern and Central European countries, Springer.

Pusterla F, Resmini L (2007) Where do foreign firms locate in transition countries? An empirical investigation. Ann Reg Sci 41(4):835-856

Ramajo J, Hewings GJD (2018) Modelling regional productivity performance across Western Europe. Reg Stud 52(10):1372-1387

Resmini L (2007) Regional patterns of industry location in transition Countries: Does the economic integration with the EU matter? Reg Stud 41(6):747-764

Rodríguez-Pose A (2018) The revenge of the places that don't matter (and what to do about it). Camb J Reg Econ Soc 11(1):189-209

Schwab K (2017) The fourth industrial revolution. Crown Business, New York

Simonazzi A. (2015). Wanted: An industrial policy for the Southern European countries. The case of Italy. In: F. Gerlach, M. Schietinger, \& A. Ziegler (Eds.), A strong Europe-but only with a strong manufacturing sector (pp. 146-172). Marburg: Schüren Verlag

Smętkowski M (2013) Regional disparities in central and eastern european countries: trends. Driv Prospect Europe-Asia Stud 65(8):1529-1554

Smetkowski M, Wójcik P (2012) Regional convergence in central and eastern european countries: a multidimensional approach. Eur Plan Stud 20(6):923-939

Villaverde J, Maza A (2008) Productivity convergence in the European regions, 1980-2003: a sectoral and spatial approach. Appl Econ 40(10):1299-1313

Publisher's Note Springer Nature remains neutral with regard to jurisdictional claims in published maps and institutional affiliations. 